\title{
Afterwords
}

\section{Hope and Education in Dystopic Times: Thinking about the Present as if from the Future}

Lynn Mario T. Menezes de Souza*

*Universidade de São Paulo (USP), São Paulo, São Paulo / Brasil lynnmario@gmail.com

http://orcid.org/0000-0001-8831-7034

Walkyria Monte Mor**

**Universidade de São Paulo (USP), São Paulo, São Paulo / Brasil walsil@uol.com.br

http:/ / orcid.org/0000-0003-0303-8664

We are impressed to read so many insightful and critical articles in this volume. They will surely fill the readers' hearts with hope, considering that dystopia, present in the background of all the articles in the form of the pandemic, does not necessarily come to the fore in many of the authors' minds, at this historical moment.

We have identified three strands of concern and philosophical reflection throughout the articles that have led us to interact with the ideas we pose below. The first is related to the world, the planet, society and citizens, rethinking the meanings that had become common currency by so many for so long. The second relates to reflections about crisis/ crises, for understandable reasons. These attempt to explain or build up meanings for the unimaginable dimension of the pandemic catastrophe that has overwhelmed the world. The third strand reveals anxiety in relation to expectations of the future. The interrogations concerning the future underlying many of the articles reveal uncertainties about the possibility of a return to pre-pandemic normality at the same time as they also reveal uncertainty as to whether what used to be called normality - now, 'old normality' - has ever really been 'normal'. 
The concept of the world as 'given', 'normal' or natural has been radically deconstructed in recent philosophy as well as by anti-colonial, postcolonial and decolonial thinkers who question the universality of such an idea. In the 1950's, Fanon, in his anti-colonial writings, showed how colonial thinking constructed a "zone of being" and a "zone of non-being" (1967). Everything pertaining to the colonial community, culture and language and its sense of 'world' lay in the "zone of being"; it existed. Everything pertaining to the colonized peoples, their culture and their community lay, for the colonizer, in the "zone of non-being", and its existence was not only devalued but also denied. In response, Fanon called for the existence of the colonized to be recognized.

Decades later, once many of the former European colonies had acquired independence, many post-colonial thinkers counterposed constructions of reality of the colonial culture with those of the colonized cultures in an apparent bid for the construction of an "authentic" postcolonial reality. Thus, Said (1978) showed how European representations of Eastern "reality" were actually constructions and not representations; Said showed how Europeans saw and represented the Orientals that they had colonized and subjugated as exotic and submissive. What emerged from this discussion was that all representations are in fact constructions by someone, of something, from a particular context, for a particular purpose. What we learned from this was that, though all representations are situated constructions, they are also products of power. The constructions of the powerful become "reality" and "representations" and those of the powerless become only fanciful and local depictions. The strategy of some post-colonial critics to counterpose a "real/authentic" reality (their own) with a more powerful "constructed" reality (of the colonizer) would be doomed to lose.

Learning from these lessons, Latin American thinkers, from their experience of having become independent from Europe more than a century before Asia and Africa, perceived that it was not fruitful to simply counterpose different constructions of reality. In order to change the power inequality between the opposing constructions of reality, they sought to show how the colonial construction of reality was created. For Santos, in order to confront the inequality inherited from colonization, it was not sufficient to simply critique it; as he says, "there can be no social justice without cognitive justice" (2014, p. vii). 
This encapsulates the need of decolonial thinkers to emphasize social constructions as epistemological constructions, or products of knowledge. Santos (2018, p. 2) makes it clear that he is not using the word "epistemology" in the same way that European philosophy does, tracing its origin to Greek philosophy. He uses the word to refer to "knowledges born in resistance and struggle" and insists on the need for decolonial thinking to "occupy the hegemonic conceptions of epistemology", recuperating the political meaning of "occupy" as to resist (http:/ / occupywallst.org).

Decolonial thinking goes beyond the common post-colonial strategy of counterposing colonial and colonized constructions of reality; by showing all constructions of reality as knowledge constructions, decolonial theory seeks to reveal the colonial strategy of concealing the authors of their constructions of reality, thus disconnecting them from particular bodies, histories and places and making them universal (GROSFOGUEL, 2011). This reveals the powerful colonial strategy through which the colonizers made themselves invisible as authors of their constructions, thus acquiring epistemological universality, to their advantage, whereas at the same time they denied existence and thus visibility to the colonized in general. A consequence of this denial was the discredit attributed to authors from colonized cultures; their knowledges and constructions could only aspire to local, reduced validity in comparison to the universal validity of colonial constructions of reality.

This denial of the existence of colonized subjects makes the issue of social constructions of reality go beyond the epistemological; it becomes onto-epistemological. As such, by recuperating issues of existence and meaning-making bodies, decolonial thinking brings into the discussion of conflicting constructions of reality the question of race, which traditional Marxian critique had considered as less relevant than social class. Quijano (2000) shows how, rather than racism per se, colonization produced racialization as a result of the colonial difference. In their first contacts with recently colonized natives, and overcome by the radical difference that everything (language, culture, etc.) pertaining to the natives represented to the European colonizer, the colonizer responded by attributing inferiority to the native and superiority to himself. A metonym for the perceived inferiority of the colonized native was his most visible aspect - the colour of his skin. 
There was as yet no concept of race, but of inferior beings (supposedly without God, without language, without culture). Skin colour thus emerged as a marker and a consequence of the perceived inferiority of the native; this was then transformed into the cause of the inferiority, eliminating its authors - the European colonizers, from the whole process of stigmatization. Thus emerged the process of racialization in which skin-colour is used to metonymically mark the inferiority of the native as well as the inferiority of his language, culture and values. This complex process reveals the violence inherent in the apparently inoffensive conflict between opposing constructions of reality.

So, for us as critical educators, reality has been constructed. As a result, society and citizens have equally been constructed. For long we have realized that the society in which we live has not been built up naturally as one or many may suppose. Though it is now almost a cliché to say that society is a social construction, this may have different meanings. To some, the idea that something is socially constructed implies a naturalized means, a natural environment, in which the social applies to people living in social groups. To others, seeing society as socially constructed means that there is $a$ project of society to which we are expected to assimilate and respond. By the word project we mean that determined ideologies and philosophies have been accepted by a determined group of people who found sense in them; these gradually found adhesion among men and women, and gained the appearance of a natural way of thinking of and viewing the world. These ideas have been taken as a natural course of social life. However, this view of social construction involves a way of organizing society as if there were a core in which the prescription of what is 'normal' or 'civilized' should be maintained. Whatever appeared different from that prescription should then be attributed the invisibility of the unaccepted in a zone of non-being or allowed the possibility of a process of becoming - undergoing transformation; but in this case, the only transformation possible was one that followed prescribed norms, turning what was transformed into part of the central core.

For long this view of the world and society has taught the learning subject what his/her citizenship should be like, where his/her locus should be situated, what identity he/she should adopt, as well as his/her likes and dislikes (BOURDIEU, 1996). In addition, all these were organized in a hierarchy that became what Geertz (1973) calls consensus gentium in the 
Enlightenment perspective, "a consensus of all mankind, the notion that there are some things that all men will be found to agree upon as right, real, just, or attractive and that these things are, therefore, in fact right, real, just or attractive" (p. 38-39). This consensus was turned into a criterion in the construction and preservation of society, making social and cognitive differences sound inherent to each human being regardless of the social conditions in which they were born or grew up.

But, again, this is violence. It reminds us that, when we speak of constructions of reality, it is not simply a matter of relativistically and liberally permitting the existence of competing construction of reality, competing habitus or competing consensus gentium. The consequences of a particular habitus or consensus gentium may be extremely violent.

At this point, we need to paraphrase Freire ([1980] 2001) to pose our next interrogation: why do people think the way they think? Do they learn from life? From fiction? From who... where? Does fiction reflect reality or viceversa?

When we discuss the world, the planet, society and citizens, what really matters in the fiction-reality or authentic-false relationship is the undeniably mutual learning between the two competing constructions. In face-to-face meetings, for years we have debated the fictionally real/really fictional societies, citizens, planets and worlds that have been created in movie screenplays in which one or more characters does/do not realize - or takes/take long to realize - that his/her/their lives are but a social construction that even allows social, emotional, political - and manipulative decisions. A depiction that contrasts with a natural course of life in which he/she/they has/have control. When these discussions were current, we focused on characters in movies like Truman, in Truman Show (WEIR; NICCOL; RUDIN, 1998), Alex's mother in Good-bye, Lenin (BECKER; LICHTENBERG; VON BORRIES, 2003) and most of the villagers in The Village, (SHYAMALAN; RUDIN, 2004), whose plots respectively read:

Truman's hometown of Seahaven Island is a complete set built within an enormous dome and populated by actors and crew members, allowing Christof to control almost every aspect of Truman's life, including the weather. https://en.wikipedia. org/wiki/The_Truman_Show 
In 1990, to protect his fragile mother from a fatal shock after a long coma, a young man must keep her from learning that her beloved nation of East Germany as she knew it has disappeared. https://www.imdb.com/title/tt0301357/

Residents of the small, isolated, 19th-century Pennsylvania village of Covington have constructed a large barrier of oil lanterns and watchtowers to protect themselves from nameless humanoid creatures living within the surrounding woods. Only Chief Elder and his blind daughter know the creatures are actually members of their own community wearing costumes of monsters to deter others from leaving the village. https:// en.wikipedia.org/wiki/The_Village_(2004_film)

These debates concentrated on worldviews and the awareness / unawareness of control/of power relations, unmasking their social-political constructions at a certain moment. The moment of unmasking is usually the point when viewers are impelled to remake taken-for-granted meanings. In more recent fictional portraits, though, we sense that the world, the planet, society and citizens have been depicted in dystopic assemblages and the difficulty to remake meanings leaves a void to be filled up. To exemplify this, we refer to the movie The Platform (GAZTELU-URRUTIA; DESOLA; RIVERO, 2020), whose screenplay focuses on

A vertical prison with one cell per level. Two people per cell. With two beds on either side of the room, there is a giant rectangle hole in the ceiling and floor of each room, and every day, a giant platform of food descends from the top all the way down to the bottom floor. Those at the top feast well, those in the middle live on scraps, and those on the bottom live and die in despair when the bones are picked clean. Available at: https://www.imdb.com/ title/tt8228288/

Another movie, Parasite (BONG, 2019), described as a black comedy thriller, portrays

a poor family who scheme to become employed by a wealthy family and infiltrate their household by posing as unrelated, highly qualified individuals. The author himself has referred to Parasite as an upstairs/downstairs or "stairway movie", in which staircases are used as a motif to represent the positions of the families in the homes of the Kims and the Parks, as 
well as the basement bunker. The film has been considered as a reflection of late-stage capitalism, and some have associated it with the term "Hell Joseon", a satirical phrase translated from Korean that describes how living in hell would be exactly like living in modern South Korea. This term came about due to high rates of youth-unemployment and requirements of higher education, the crisis of home affordability, and the increasing socio-economic gap between the wealthy and poor. Available at: https://en.wikipedia.org/wiki/Parasite_ (2019_film)

Dystopia prevails in both. Can we interpret that the pandemic energy that has spread since 2019 has contaminated our views of the world? Or that it has opened our eyes to make revisions? By reading the articles in the current volume we sense the underlying uncertainties and interrogations towards the future, but it seems that a thread of hope underpins most of the thoughts.

What crisis is it? Putting this into the current perspective of the covid-19 pandemic, in which, besides the hundreds of thousands of lives that have been lost, many of us have also lost our utopias, on varying points of the political spectrum. This loss has been replaced by the current dystopia and the popular strategy of speaking of a "new normal" that masks the violence of this loss. In whose interest does the construction of a "new normal" function? If one considers that the term "new normal" encourages that "life must go on", in our present economic paradigm this justifies and reinforces the neo-liberal construction of reality where the market and the economy are primordial and as citizens, one needs to continue working to keep the economy going. The "new normal" encourages us to work and exploit ourselves to the point of exhaustion. The same has happened to the planet. Hasn't it also been exploited to the point of exhaustion? We have internalized the neoliberal individualistic values of freedom, non-regulation, competition and deserved merit which form the basis of our current doxa to the extent that, as educators and academics, we believe we are free to do as we please, but this must include the imperative of continuing to work and produce. In our current dystopia, the previously perceived rewards of our work efforts (pleasurable moments in restaurants, shows, holidays, travels etc) are no longer possible or only precariously possible. But, as victims of the new normal, we go on producing even without the possibility of rewards. 
Is it not time we reflected on this dystopia? Or at least on how violent our construction of reality, our very own onto-epistemologies are? We may be conscious of the politics behind our choice of a particular social construction of reality - on the right of the political spectrum, this may involve, among other things, privileging individual liberty, personal profit and the maintenance of the status quo. On the left of the spectrum, it may involve emphasizing the social collective, the redistribution of wealth and social benefits and a transformation of the status quo. But the dystopia of the pandemic is affecting us all; not equally, as depending on our means and privileges, our suffering may be increased or reduced, but not eliminated. New or old, is this "normal"?

Is there a point from which we can safely, neutrally and objectively judge the truth-value and violence of one construction of reality in relation to another?

The Belgian thinker Isabelle Stengers (2005), as an anthropologist facing conflicting social constructions of reality, proposes the concept of cosmopolitics. The basis of this proposal is that there is no common basis shared by all; no common habitus or consensus gentium. There is also no possibility of not being part of a social construction. We are always already part of a social construction and we can only judge a social construction from the perspective of another social construction.

The only thing we, in our various social constructions, have in common is a cosmos, a liminal non-space in which all social constructions co-exist. At the same time as it is not possible to not be part of a social construction, no single social construction of reality can claim to be founded on certainty. The liminal non-space of the cosmos offers only one certaintythat multiple social constructions of reality exist and collide.

So, what does this concept of cosmos offer? For Stengers (2005, p. 996), it "has nothing to do with a program and far more to do with a passing fright that scares self-assurance, however justified". It offers us an ethic of the need to be open to plurality and the possibility of being wrong. Above all, it alerts us that all our social constructions, including language, culture and politics, are incomplete and in a constant process of becoming. It is not relativity which claims that we all see the same thing from different perspectives; it shows us that there is no "same thing" we can all see. It tells us that in terms of meaning-making and inequalities of power, we are all 
in this together, whether we like it or not. Thus, what can we foresee from now on?

In our area of education, literacies and languages, are we waiting for Godot? Will it come? What to expect from the future?

We have been led to the reflections here posed by the issues raised in this volume. The pandemic underlies most of them, reinforcing a feeling of emergency in the face of contingency. Hardly ever had we been impelled to tackle issues we had been concerned about for so long. And one still remains: in order to rethink society, the planet, citizens, should education be given different roles from now on? What should it be like? Some would say these are million-dollar responses.

A few authors such as Darling and Nordenbo (2003) and Irwin (2012) believe that the now-evidenced educational crisis was actually surfaced by Freire in his Pedagogia do Oprimido (1987). To Irwin (2012), this is the publication in which Freire untangled 'significant gaps between existing arrangements and perceived societal and cultural needs", the terms he uses to politely refer to the Brazilian inequities discussed in Freire's book. As for us, by discussing oppression, inequities and discrimination, Freire (1987) opens up the lid of Pandora's box of coloniality, turning it into a widely acknowledged contribution to the works on critique and critical awareness (consciência critica / conscientização) and to the more recent focus on decolonization.

Freire's is a pedagogy of hope. Spinoza reminds us in the Ethics (2000, p. 19), that Hope and Fear are connected such that there is neither Hope without Fear, nor Fear without Hope. For Spinoza, both Hope and Fear are characterized by doubt. Whereas Hope refers to a pleasurable image of something past or future of which we are not certain, Fear refers to an image of pain of which we are also in doubt. When the element of doubt is removed, Hope becomes Confidence and Fear becomes Despair. If, for Spinoza (2000, p. 55) Disappointment is the remembrance of the pain of something past, and Hope refers to a pleasurable image, then we could say that Disappointed Hope is a pleasurable image of the future accompanied by the remembrance of past pain. This is still an image marked by doubt but a doubt that affords agency rather than debilitating agency.

Based on Spinoza, Santos (2018, p. 293) describes Fear and Hope as being unequally distributed in social terms: whereas the less privileged receive abundant Fear, the elite receives abundant Hope. For Santos, the 
Fear of the underprivileged indicates the complete loss of Hope and the sinking into desolation and non-agentivity. On the other hand, the Hope of the elite not only indicates complete loss of Fear but also the acquisition of such absolute confidence that their actions, which provoke the Fear and desolation of the underprivileged, continue unhindered.

Also reflecting on Hope and Fear, Bloch (1995) sees Fear as passive, incapacitating action and Hope as open to new possibilities. However, for Bloch, for whom life is never static but always a process of flux and becoming, in order to avoid Hope as something passive, referring to pleasurable images to be passively received (as in a daydream of a pleasurable future), Hope has to be learned: one needs to actively and rationally think through the pleasurable images of Hope; one needs to let the Hope of the New in the daydream "grow really fuller, that is, clearer, less random, more familiar, more clearly understood and more mediated". One needs to grasp "the New as something that is mediated in what exists and is in motion; although to be revealed, the New demands the most extreme effort of will"' (1995, p. 4). Thus, for Bloch, Hope, in order to go beyond something passive, requires active thinking about how what exists can be transformed into something New. This can be learned by thinking about the present as if from the future, by starting from the pleasurable image of the future one hopes for and, from this, start to actively transform the present.

Bhabha (2018) offers an example of this in the disappointed hope of the African migrants; they actively abandon their situations of suffering and actively and willingly work towards realizing the possibility of a dreamed future; their memory of fear and pain in the past together with their desire for a better future gives them the energy and capacity to face the extreme difficulties of migrating to an unwelcoming global North.

The crisis in education is still under the spotlights of educational policy debates. The focus on the past of education has brought several insights to research and practices. However, defuturing the future (by this we mean knowing what has been prospected for the future of education by researchers dedicated to this theme) may lead us to see a little bit farther. We need to think through the dystopia and fear of the present as if from the hope of the future. But not a passive, naive hope; an active hope of reflected agentivity and action.

Concordia University young academic Reznichek, founder at TeacherGamer, author of the Teacher-Gamer Handbook, considered an innovator 
in education, makes use of the debatable term 'authentic' in his defense of an "authentic education" (2021) as he counters the modernity-loaded curriculum of today. The traditional curriculum is seen by Reznichek as unauthentic, having a mentality-shaping design that responds to what we have named here a modernity-like project of society. To him, the curriculum should be designed to contemplate performance learning of a number of feats in a way to enable young people "to survive planetary conditions (social, fiscal, and environmental) on one's own, receiving a clear understanding of the actual state of the planet being inherited upon reaching adulthood". And he adds: "hope' is not activism" (p. 1). Like the disappointed hope of the African migrant that propels towards action despite the memory of fear and pain, education can seek to develop reflected agentivity beginning in the midst of current dystopia, thinking through the difficulties of the community, the world, the planet. Our vision of better times should not paralyze us in the present but, on the contrary, implement us to work through our current obstacles.

With a similar concern about the planet, the world and a different human being in the future, Biesta (Forthcoming) visualizes a world-centred education - the world where our existence as human beings takes place - rather than the more common child-centred or curriculum-centred educational practices that currently prevail. As one can read in the author's personal site (https:/ / www.gertbiesta.com/), this design reinforces the idea of

(re)directing the attention of students to the world, so that they may encounter what the world is asking from them and highlights the unique position of the school as the place where the new generation is given the time to meet the world and meet themselves in relation to the world

As for Literacies as a 'new education' proposal, in an interview, Garcia, Luke and Seglem (2018) assess the two decades of Literacies practices, wondering why "the world and communities can be burning down around us, and educational debates seem to default to ideological red herrings of phonics and 'back to the basics"'. In this conversation, their disappointment with the overwhelming power of neoliberalism over new projects is evidenced. At the very starting point, they warn, the proposal has privileged issues like "the deskilling of labor, the marginalization of 
women, the neglect toward minorities and the urban poor". Since then, it has struggled to preserve its rationale, while neoliberalism has greatly worked on the colonization of Multiteracies. In their words, this attempt is noticed when people pursue "to incorporate it into the very heart of neoliberalism"; "to redefine it as a measurable domain of curriculum for standardized assessment"; to turn it into "the object of commodification, with curriculum packages, approaches, methods and materials offered by publishers, corporations and consultants". If on the one hand they seem to draw a dystopian scenario, on the other, their advice reassures the need for resistance and the practice of digital ethics, multiliteracies and critical citizenship at the core of the curriculum aimed at educating for social justice.

In Brazil, despite neoliberal and political odds, the participants of the Nation-wide Project on Literacies have tirelessly worked towards this purpose. The articles in this edition are evidence of this.

\section{References}

BECKER, W.; LICHTENBERG, B.; VON BORRIES, A. (Director; Writer; Producer, respectively). Good-bye, Lenin. X-Film Creative Pool, Germany. 2003. Available at: https://www.imdb.com/title/tt0301357/.

BHABHA, H. Migration, Rights, and Survival: The Importance of the Humanities Today. From the European South, Padova, v. 3, p. 7-12, 2018.

BIESTA, G. World-Centred Education. A View for the Present. London; New York: Routledge. Forthcoming. Preview 2021.

BLOCH, E. The Principle of Hope. Cambridge, Mass.: MIT Press, 1995. v. 1. BONG, J. H. (Screenplay Writer; Director). Parasite. Barunson E\&A Corp. South Korea, 2019. Access: https://en.wikipedia.org/wiki/Parasite.

BOURDIEU, P. A economia das trocas linguísticas. Transl. Sergio Miceli et al. São Paulo: EDUSP, 1996.

DARLING, J.; NORDENBO, S. F. Progressivism. In: BLAKE, N. et al. (ed.). The Blackwell Guide to Philosophy of Education. Oxford: Blackwell, 2003. p. 288-308. DOI: https://doi.org/10.1002/9780470996294.ch17

FANON, F. Black Skin, White Masks. New York: Grove Press, 1967.

FREIRE, P. Pedagogia do oprimido. 28. ed. Rio de Janeiro: Paz e Terra, 1987. 
FREIRE, P. Conscientização: teoria e prática da libertação. Uma introdução ao pensamento de Paulo Freire. 3. ed. São Paulo: Centauro Editora, [1980] 2001. GARCIA, A.; LUKE, A.; SEGLEM, R. Looking at the Next 20 Years of Multiliteracies: A Discussion with Allan Luke. Theory Into Practice. v. 57, n. 1: Twenty Years of Multiliteracies: Moving from Theory to Social Change in Literacies and Beyond, p. 72-78, 2018. DOI: https://doi.org/10.1080/004 05841.2017.1390330

GAZTELU-URRUTIA, G.; DESOLA, D.; RIVERO, P. (Director; Screenplay Writers, respectively). The Platform. Basque Films; Mr. Miyagi Films; Plataforma La Película; A.I.E. Spain, 2020. Available at: https://www. imdb.com/title/tt8228288/.

GEERTZ, C. The Impact of the Concept of Culture on the Concept of Man. In: The Interpretation of Cultures. New York: Basic Books, 1973. p 31-54.

GROSFOGUEL, R. Decolonizing Post-Colonial Studies and Paradigms of Political-Economy: Transmodernity, Decolonial Thinking, and Global Coloniality. Transmodernity: Journal of Peripheral Cultural Production of the LusoHispanic World, Merced, CA, v. 1, n. 1, p. 1-38, 2011.

IRWIN, J. Paulo Freire's Philosophy of Education. Origins, Developments, Impacts and Legacies. London; New York: Continuum International Publishing, 2012.

OCCUPY. Available at: http:/ / occupywallst.org.

QUIJANO, A. Coloniality of Power: Eurocentrism and Latin America. Nepantla: Views from the South, Durhan, NC, v. 1, n. 3, p.533-583, 2000.

REZNICHEK, Z. What is 'Authentic Education'? Academia Letters, [S.l.], Article 887, May 2021. Open Access. Distributed under CCBY 4.0. DOI: https://doi. org/10.20935/AL887.

SAID, E. Orientalism. New York: Pantheon, 1978.

SANTOS, B. de S. Epistemologies of the South: Justice Against Epistemicide. Boulder: Paradigm Publishers, 2014.

SANTOS, B. de S. The End of the Cognitive Empire: The Coming of Age of Epistemologies of the South. Durham: Duke University Press, 2018. DOI: https:// doi.org/10.1215/9781478002000 
SHYAMALAN, M. N.; RUDIN, S. (Screenplay Writer and Director; Producer, respectively). The Village. Touchstone Pictures, Blinding Edge Pictures, Scott Rudin Productions. USA. 2004. Available at: https://en.wikipedia.org/wiki/The_Village SPINOZA, B. The Ethics: Part III - On the Origin and Nature of the Emotions. Hazleton: Pennsylvania State University, 2000.

STENGERS, I. The Cosmopolitical Proposal. In: LATOUR, B.; WEIBEL, P. (ed.). Making Things Public. Cambridge, MA: MIT Press, 2005. p. 994-1003.

WEIR, P.; NICCOL, A.; RUDIN, S. (Director; Screenplay Writer; Producer, respectively). The Truman Show. Paramount Pictures, Scott Rudin Productions. USA, 1998. Available at: https://en.wikipedia.org/wiki/The_Truman_Show. 